\title{
Higher Education Teachers' Training in Attention to SEN Students: Testing a Mediation Model
}

\author{
Nuria González-Castellano ${ }^{1, *(D)}$, Eulogio Cordón-Pozo ${ }^{2}$, , Silvia Pueyo-Villa $^{3}$ \\ and María Jesús Colmenero-Ruiz ${ }^{1}$ (D) \\ 1 Department of Pedagogy, University of Jaén, 23071 Jaén, Spain; mjruiz@ujaen.es \\ 2 Department of Business Organization II, University of Granada, 18071 Granada, Spain; ecordon@ugr.es \\ 3 Department of Language and Education, European University of the Atlantic, 39011 Santander, Spain; \\ silvia.pueyo@uneatlantico.es \\ * Correspondence: ngc00008@red.ujaen.es
}

Citation: González-Castellano, N.; Cordón-Pozo, E.; Pueyo-Villa, S.; Colmenero-Ruiz, M.J. Higher Education Teachers' Training in Attention to SEN Students: Testing a Mediation Model. Sustainability 2021, 13, 4908. https://doi.org/ $10.3390 /$ su13094908

Academic Editors: Fernando José Sadio Ramos, José Antonio Marín-Marín and Santiago Alonso-García

Received: 22 March 2021

Accepted: 24 April 2021

Published: 27 April 2021

Publisher's Note: MDPI stays neutral with regard to jurisdictional claims in published maps and institutional affiliations.

Copyright: (c) 2021 by the authors. Licensee MDPI, Basel, Switzerland. This article is an open access article distributed under the terms and conditions of the Creative Commons Attribution (CC BY) license (https:/ / creativecommons.org/licenses/by/ $4.0 /)$.

\begin{abstract}
There is growing interest in analyzing the evolution of inclusive education in universities, highlighting the training of teachers as the main barrier to this evolution. The purpose of this study was to analyze, through a mediation model, to what extent the accessibility and inclusion of university campuses affect, both directly and indirectly, the continuous training of teachers in attention to diversity and training demands by teachers in this same area. Participants were 580 teachers from the Faculty of Education of eight Andalusian universities (Spain). The results revealed that the continuous training of teachers in attention to diversity mediates the negative effect that accessibility and inclusion of university campuses have on the training demanded by teachers; this means that the more accessible and inclusive the universities are, the more continuous training teachers have and therefore the more interest they have in continuing training. There is no empirical evidence in the literature that this mediation model is used in the field of educational inclusion as a methodological technique, so it is a very innovative contribution.
\end{abstract}

Keywords: university; inclusive education; teachers; training; mediation model; special educational needs (SEN)

\section{Introduction}

Higher education is facing new challenges that have not been previously considered $[1,2]$ such as the growing presence of students with special educational needs (SEN) [3]. The prevailing legal framework at the country level and the recommendations of supranational organizations make it necessary to respond to the needs of students with special educational needs through inclusive educational processes and sustainable universities [4]. Clear examples are the 2030 Agenda for Sustainable Development [5], the Convention on the Rights of Persons with Disabilities [6], the European Union's commitment through the European Strategy 2010-2020 [7], or the European Agency for Special Needs and Inclusive Education [8]. This legislation provides for the right of students with special educational needs to have access to education, as well as promoting a society that respects equal opportunities and non-discrimination. If we focus on Spain, the rights of students with special educational needs are set out both in the Organic Law on Universities [9] and in the Royal Decree approving the University Student Statute [10], establishing that university environments must be accessible, implement support programs, and provide the necessary resources to create inclusive contexts.

However, legislation in this area is not sufficient. On the one hand, it is also necessary to have an internal organization in the university willing to provide completely inclusive education [1]. On the other hand, teachers play a fundamental role, since the way they carry out the teaching-learning process influences the permanence and academic success of students with special educational needs [11]. Consequently, the training of teachers in 
attention to diversity is a key element to improve the quality of teaching and inclusion in universities [12-14]. Therefore, both teachers and universities should receive recommendations to design sustainable learning environments for everyone. In this sense, the link between the university, its services, and teachers is essential so that students with special educational needs can have equal learning opportunities [15,16].

The objective of this article, as one of the first studies in this area carried out with a mediation model, is to analyze the effect that the continuous training of teachers in attention to diversity has on the process of training demand in attention to diversity that the teachers request from the university. This article also considers the impact of the level of accessibility and inclusion to the university campus over these variables. Fundamentally, it is hypothesized that the level of teachers' continuous training in areas related to attention to diversity mediates the impact of the level to which the university campus is accessible and inclusive on the training demands in this area.

More specifically, this work analyzes the direct and indirect effects of the level of accessibility and inclusion of eight universities in the Autonomous Community of Andalusia through the teachers' continuous training in attention to diversity and their demands for this training from the university. It controls the effect of those factors which the literature has identified as related to the variables of interest, such as gender, age, area of knowledge, and whether or not they have had students with special educational needs in their classes (see Figure 1).

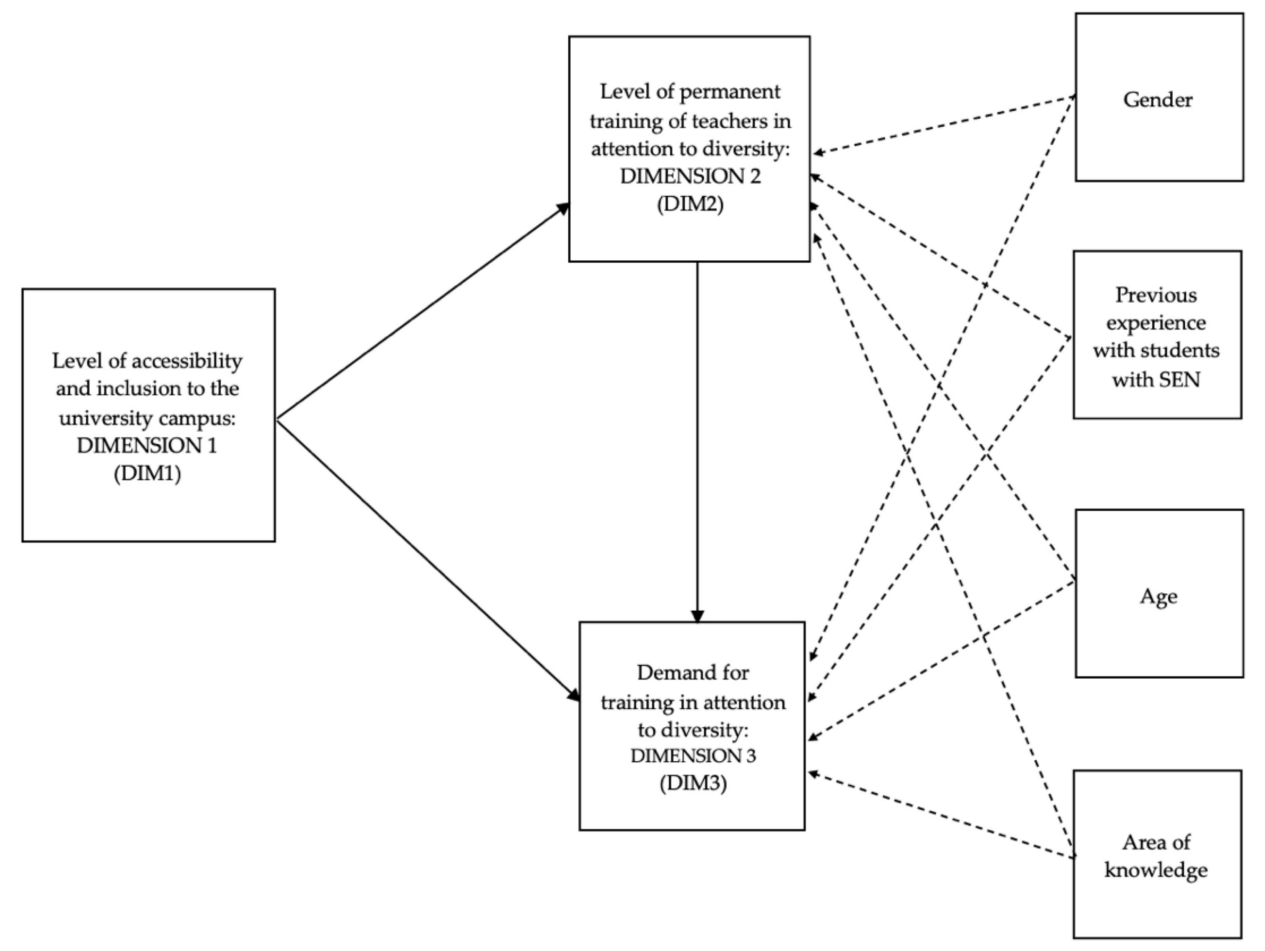

Figure 1. Mediation model to be tested.

\subsection{Teachers' Continuous Training in Attention to Diversity}

Teachers' continuous training in both their area of knowledge and issues related to attention to diversity is crucial [16]. They are currently facing new challenges related to new teaching approaches, and they must present a training adjusted to this new context [17].

Both international and national research, which has taken into account the response of teachers, highlights a lack of training in inclusive educational processes [18,19]. Teachers have a lack of knowledge about the different types of disabilities, inclusive strategies and methodologies, and the variety of resources offered by the university [20]. Due to this lack, teachers feel insecure about addressing the needs of students with special educational 
needs and experience high levels of stress, negatively affecting their performance and attitudes towards inclusion [21].

Therefore, determining the perceptions of teachers about their continuous training in attention to diversity provides us with information about how this continuous training mediates the relationship between the level of accessibility and inclusion of the university campus and the training demands in attention to diversity of teachers from the university.

\subsection{Training in Attention to Diversity Demanded by Teachers}

Throughout the training process in attention to diversity, it is necessary to take into account the content most demanded by teachers. There are studies in which teachers request concrete and practical training, want to know their legal obligations and techniques for adapting the curriculum, and request training in the use of specific resources or strategies for more personalized attention [22-24].

Therefore, with this information, universities can design and develop training programs for teachers in attention to diversity [2] and thus have teachers who are trained to respond adequately to the needs of students with special educational needs and create a sustainable environment adapted to disability [25]. In view of these findings, no studies were found that analyze the direct and indirect effects that the level of accessibility and inclusion of the university campus has on the training demanded by teachers in terms of attention to diversity.

\subsection{Effect of Factors Influencing Teachers' Perceptions towards Educational Inclusion}

The scientific literature has focused on analyzing inclusion in higher education by contemplating the teachers' perceptions and highlighting several determining factors that influence the evolution of inclusive education in universities. One of the factors studied has been the teachers' gender. We found studies that did not detect any differences in attitudes towards inclusion between men and women [26,27]. However, in other studies, women present more positive attitudes than men $[28,29]$, unlike another study that claimed that it is men who present a more positive attitudes than women [30].

On the other hand, some studies take into account other factors that influence teachers' attitudes towards inclusion such as the level of training presented in attention to diversity. Some studies consider that the more training the teachers have, the more positive their attitudes are towards inclusion [22,31]. Other studies consider that a lack of training negatively influences their inclusive attitudes and practices $[18,32]$.

Another factor that influences attitudes is the teachers' age. It was determined that younger teachers have a less positive attitude towards inclusion [33]. However, other studies found contrasting results $[27,34]$. Previous work with people with special educational needs is also considered as a factor that influences teachers' attitudes positively [30,35]; however, in another study it was not considered as a determining factor [27]. Finally, another factor to take into account is the teachers' area of knowledge, since depending on which area they specialize in, their educational demands and perceptions about inclusion are going to vary $[27,36]$.

In this study, we controlled for the potential effect of different factors (including gender, age, previous experience with students with special educational needs, and area of knowledge) on the variables of interest we considered, taking into account the proposed model of mediation.

\subsection{The Current Study}

Given the importance of making higher education sustainable and inclusive, as well as that teachers are trained in attention to diversity so that students with special educational needs can advance in their teaching-learning process without obstacles, the main objective of the current study was to analyze the effect of the level of accessibility and inclusion of various university campuses on the training in attention to diversity that the teachers 
request. From this main objective, several questions arise that will be answered throughout the research process:

1. What is the impact of the level of accessibility and inclusion of the university campus on the continuous training of teachers in attention to diversity and their training demands from the university?

2. What is the effect that the continuous training of teachers in attention to diversity has on the training in attention to diversity that the teachers request?

3. What effect do the control variables have (gender, age, previous experience with students with special educational needs, and area of knowledge) on the variables of interest in the study?

\section{Method}

\subsection{Participants}

The sample for this study was composed of teachers who teach in Faculties of Education of the different universities of the Autonomous Community of Andalusia (Spain). Stratified random sampling was used to guarantee the representativeness of the sample. Before the data collection process, the optimal sample size was estimated for a $95 \%$ confidence level and a maximum error rate of $5 \%$. The calculations yielded an optimal sample size of 323 subjects, a figure vastly exceeded by the obtained 580 valid responses ( $46 \%$ male and $54 \%$ female). Although teachers from all Andalusian universities are present in the final sample, the presence of teachers from the universities of Jaén (23.8\%), Seville (19.0\%), and Granada (15.2\%) is highlighted. The teachers' average age was 45 years. Regarding the teachers' areas of knowledge, we found the areas of education (57.4\%), psychology $(22.1 \%)$, history/sociology (5.9\%), and philology (17.7\%). Of the surveyed teachers, $12.1 \%$ have never taught classes to students with special educational needs (see Figure 2), and $39 \%$ have not attended complimentary training courses related to attention to diversity.

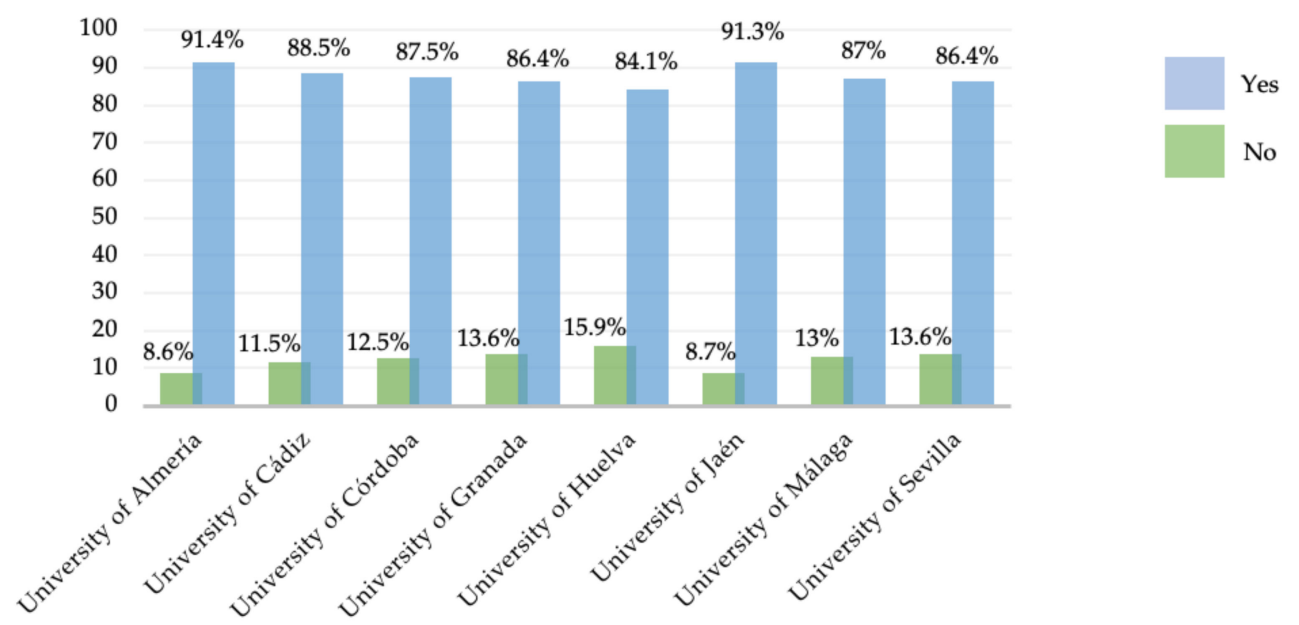

Figure 2. Teaching experience at the university with SEN students.

\subsection{Instrument and Procedure}

For this research, a survey was used as the main method of data collection. The questionnaire was structured in three main sections, and some sections of this tool have been used for this study. The first section related to collecting socio-demographic data of the participants, such as university, gender, age, length of time as a teacher at the university, professional category, area of knowledge, teaching experience at the university with students with special educational needs, and complementary training courses related to attention to diversity. The second section included short dichotomous questions (yes/no) on the teachers' attitudes towards the inclusion of students with special educational needs at the university. The third section related to the "APTD scale" [37], which is a Likert-type 
measure, with answers ranging between 1 and $7(1=$ totally disagree, $7=$ totally agree $)$ made up of 21 items distributed across different dimensions/factors:

A. Accessibility to the university campus: detects the barriers that limit the access of students with special educational needs to the university campus.

B. Actions and inclusive educational processes: identify how teachers respond to students with special educational needs in their classes.

C. Permanent Training: analyzes the continuous training of teachers in their processes of attention to diversity.

D. Demanded training: examines the training in attention to diversity that teachers request.

The name of the scale was APTD due to the different factors comprising it: accessibility to the university campus; actions and inclusive educational processes; permanent training; demanded training. However, in this study, we have only focused on the first, third and fourth dimension.

The proposed research was carried out in the Faculties of Education of the different universities of the Autonomous Community of Andalusia (Spain). To make this decision, we reviewed the studies published by the Universia Foundation [38-40]. In these studies, it is reflected that students with special educational needs are more inclined to studies related to the branch of knowledge of social and legal sciences. Therefore, we verified that the Faculty of Education of each of the universities covers different university degrees that give rise to a diversity of areas of knowledge related to the social sciences. The questionnaire was completed between January 2019 and April 2019. The questionnaire was sent in the form of a Google form link via email to the entire population $(\mathrm{N}=2.025)$, and the responses were received automatically via Google Drive. To avoid possible biases in the research, such as failures in the reception of the email or transfers to the spam folder, a second message was sent in March. Finally, in the month of April, the questionnaire was closed, with a total of 580 valid responses. The following sections summarize and explain the methodological approach in detail. The study was approved by the Ethics Committee of the Vice-Rectorate for Research of the University of Jaén.

\subsection{Method of Analysis}

Statistical analysis was done using R 4.0.0 [41], the lavaan (v0.6-6) [42], MVN (v5.8) [43] and semTools (v0.5-3) [44] packages. The estimation of the mediation model was carried out using the lavaan package [42]. Since the results obtained using the MVN package indicated the impossibility of accepting the hypothesis of multivariate normality, the model could not be estimated using the ML estimation method. This, combined with the binary nature of some variables involved, prompted us to use the WLSMV estimation method available in the lavaan package [45].

\section{Results}

The main objective of this study is to test a mediation model that analyzes the direct and indirect impact of the level of accessibility and inclusion of various university campuses on the demands of teachers in specific training in attention to diversity. We also consider that the aforementioned relationship is mediated by the current level of teachers' continuous training in attention to diversity. After estimating the model, we found that the indicators of the goodness of fit are adequate (see Table 1). 
Table 1. Goodness of fit indices.

\begin{tabular}{|c|c|c|}
\hline Indices & Value & Interpretation for Guidance * \\
\hline$\chi^{2}$ & $\begin{array}{l}180.614 \text { with } 185 \text { degrees of } \\
\text { freedom }(p=0.577)\end{array}$ & $p>0.05$ \\
\hline Comparative Fit Index (CFI) & 0.950 & $\geq 0.95$ Very good fit \\
\hline Tucker-Lewis Index (TLI) & 0.942 & $\geq 0.90$ and $\leq 0.94$ good fit \\
\hline $\begin{array}{l}\text { Root Mean Square Error of } \\
\text { Approximation (RMSEA) }\end{array}$ & $\begin{array}{c}0.036 \\
\text { 90\% CI lower: } 0.029 \\
\text { 90\% CI upper: } 0.042 \\
\text { p-value RMSEA } \leq 0.05=1\end{array}$ & $\begin{array}{c}\leq 0.05 \text { very good fit } \\
p \text {-value }>0.05\end{array}$ \\
\hline $\begin{array}{c}\text { Standardized Root Mean Square } \\
\text { Residual (SRMR) }\end{array}$ & 0.037 & $\leq 0.08$ Good fit \\
\hline
\end{tabular}

Note: * Based on [45] (p. 43).

Regarding the validity and reliability of the measurement scales used in this study, we follow the recommendations of the literature on validation techniques using Confirmatory Factor Analysis (CFA) and calculated the Construct Reliability (CR) and the Average Variance Extracted (AVE) for every subscale [46,47]. Values close to or above 0.7 for CR and 0.5 for AVE were used as indicators of the internal consistency of the scales $[46,47]$. The criterion of all factor loadings being significant $p[(>|z|)<0.05]$ was used as an indicator of convergent validity [48]. In Table 2, we present the results obtained in our model.

Table 2. Evaluation of the validity and reliability of the measurement scales (standardized solution).

\begin{tabular}{|c|c|c|c|c|}
\hline Scale/Items & Estimate & Z-Value * & $p(>|z|)$ & AVE and CR \\
\hline Accessibility to the university campus (DIM1) & & & & \multirow{5}{*}{$\begin{aligned} \mathrm{AVE} & =0.6181 \\
\mathrm{CR} & =0.989\end{aligned}$} \\
\hline $\begin{array}{l}\text { 1. The University has adequate resources to offer quality training to students with } \\
\text { special educational needs }\end{array}$ & 0.766 & Fixed & & \\
\hline 2. Classroom equipment is adapted (slate heights, switches, etc.) & 0.669 & 15.429 & 0.000 & \\
\hline $\begin{array}{l}\text { 3. The University has services and supports so that students with special educational } \\
\text { needs can study normally as well as the rest of the students }\end{array}$ & 0.853 & 16.926 & 0.000 & \\
\hline $\begin{array}{l}\text { 4. The University has the means to solve any type of adaptation/modification in the } \\
\text { access to the curriculum for students with special educational needs }\end{array}$ & 0.843 & 17.332 & 0.000 & \\
\hline \multicolumn{5}{|l|}{ Permanent training (DIM2) } \\
\hline 10. I know different models and ways of carrying out inclusion in the classroom & 0.864 & Fixed & & \multirow{6}{*}{$\begin{aligned} \mathrm{AVE} & =0.6896 \\
\mathrm{CR} & =0.992\end{aligned}$} \\
\hline $\begin{array}{l}\text { 11. I know the concept of inclusive education and its educational implications in the } \\
\text { teaching-learning process }\end{array}$ & 0.778 & 23.543 & 0.000 & \\
\hline 12. I have attended training courses on attention to diversity & 0.722 & 20.671 & 0.000 & \\
\hline $\begin{array}{l}\text { 13. I know the educational needs that students with special educational needs } \\
\text { can have }\end{array}$ & 0.886 & 28.965 & 0.000 & \\
\hline $\begin{array}{l}\text { 14. I have the necessary training and qualification to adapt the material of students } \\
\text { with special educational needs and give an adequate educational response }\end{array}$ & 0.843 & 27.715 & 0.000 & \\
\hline $\begin{array}{l}\text { 15. I know specific techniques to facilitate the participation and integration of } \\
\text { students with special educational needs in my class }\end{array}$ & 0.877 & 28.217 & 0.000 & \\
\hline Demanded training (DIM3) & & & & \multirow{7}{*}{$\begin{aligned} \mathrm{AVE} & =0.6896 \\
\mathrm{CR} & =0.994\end{aligned}$} \\
\hline 16. Theoretical training on attention to diversity & 0.759 & Fixed & & \\
\hline 17. Practical training in teaching methodologies and strategies & 0.913 & 23.503 & 0.000 & \\
\hline 18. Training in the design and adaptation of educational materials & 0.935 & 26.033 & 0.000 & \\
\hline 19. Training in the use of specific means and resources & 0.931 & 24.085 & 0.000 & \\
\hline 20. Knowledge of alternative communication systems & 0.830 & 21.706 & 0.000 & \\
\hline 21. Application of personalized attention strategies & 0.904 & 23.615 & 0.000 & \\
\hline
\end{tabular}

Note: * The $\mathrm{Z}$ value is not calculated for those indicators set to unity.

To check the discriminant validity, we follow the recommendations of Voorhees et al. [49] and calculate indices proposed by Fornell and Larcker [50] and the heterotrait-monotrait ratio (HTMT) of the correlations proposed by Henseler et al. [51] with a 0.85 cut-off point. As shown in Table 3, obtained in part using the semTools package [44], the results illustrated allow us to accept the discriminant validity between the three constructs of the model. 
Table 3. Discriminant validity.

\begin{tabular}{|c|c|c|c|c|c|c|c|}
\hline \multicolumn{4}{|c|}{ Fornel and Larcker [50] AVE-SV * } & \multicolumn{4}{|c|}{ HTMT Matriz Henseler et al. [51] * } \\
\hline & DIM1 & DIM2 & DIM3 & & DIM1 & DIM2 & DIM3 \\
\hline DIM1 & 1 & 0.0324 & 0.0081 & DIM1 & 1.000 & & \\
\hline DIM2 & 0.180 & 1 & 0.0864 & DIM2 & 0.178 & 1.000 & \\
\hline DIM3 & $-0,09$ & 0.294 & 1 & DIM3 & 0.092 & 0.300 & 1.000 \\
\hline AVE & 0.6181 & 0.6896 & 0.6896 & & & & \\
\hline \multicolumn{4}{|c|}{$\begin{array}{l}\text { Note: * Correlations below the diagonal. On the } \\
\text { diagonal the shared variances (SV). AVE > SV } \\
\text { Evidence of Discriminant validity. }\end{array}$} & \multicolumn{4}{|c|}{$\begin{array}{l}\text { Note: }{ }^{*} \text { Under the diagonal all the values are } \\
\text { less than } 0.85 .\end{array}$} \\
\hline
\end{tabular}

After checking the validity and reliability of the measurement scales and the adequacy of the model fit, in Table 4 we show the results obtained after estimating it using the WLSMV method.

Table 4. Parameters estimates using WLSMV estimation method.

\begin{tabular}{cccccc}
\hline & Estimate & Std. Err. & $z$-Value & $p(>|z|)$ & Std Solution \\
\hline DIM1 $\rightarrow$ DIM2 & 0.237 & 0.065 & 3.638 & 0.000 & 0.180 \\
gender $\rightarrow$ DIM2 & 0.474 & 0.136 & 3.477 & 0.001 & 0.149 \\
SEN $\rightarrow$ DIM2 & 0.728 & 0.189 & 3.855 & 0.000 & 0.150 \\
area $\rightarrow$ DIM2 & -0.034 & 0.166 & -0.207 & 0.836 & -0.009 \\
area2 $\rightarrow$ DIM2 & -0.914 & 0.254 & -3.593 & 0.000 & -0.136 \\
area3 $\rightarrow$ DIM2 & -0.942 & 0.201 & -4.690 & 0.000 & -0.210 \\
age $\rightarrow$ DIM2 & 0.005 & 0.007 & 0.758 & 0.448 & 0.032 \\
DIM1 $\rightarrow$ DIM3 & -0.164 & 0.059 & -2.757 & 0.006 & -0.144 \\
DIM2 $\rightarrow$ DIM3 & 0.259 & 0.043 & 6.046 & 0.000 & 0.300 \\
gender $\rightarrow$ DIM3 & 0.182 & 0.113 & 1.611 & 0.107 & 0.067 \\
SEN $\rightarrow$ DIM3 & -0.095 & 0.156 & -0.610 & 0.542 & -0.023 \\
area1 $\rightarrow$ DIM3 & -0.296 & 0.147 & -2.009 & 0.045 & -0.090 \\
area2 $\rightarrow$ DIM3 & -0.484 & 0.246 & -1.970 & 0.049 & -0.083 \\
area3 $\rightarrow$ DIM3 & -0.319 & 0.183 & -1.746 & 0.081 & -0.083 \\
age $\rightarrow$ DIM3 & -0.021 & 0.005 & -3.873 & 0.000 & -0.155 \\
\hline
\end{tabular}

Regarding the control variables considered, we observe that the gender is positively related to the level of continuous training in aspects related to the inclusion of students with special educational needs $(b=0.474 ; p=0.001)$. Since this variable was coded with 0 for men and 1 for women, our results indicate that being a woman positively influences the level of continuous training in this area. However, gender is not a relevant variable when it comes to explaining the level of training demand in attention to diversity $(b=0.182 ; p=0.107)$. Similarly, the previous experience of teachers with students with special educational needs (SEN $=1$ if the teacher has previously taught students with this type of need and 0 otherwise) is a determining factor in their current level of continuous training in attention to diversity $(\mathrm{b}=0.728 ; p=0.000)$, but it does not affect future training demand in this field $(b=-0.095 ; p=0.542)$.

To analyze the effect of the area of knowledge to which the teacher belongs, we use a dummy coding scheme, where the reference category is the area of education (see Table 4). Regarding the current level of continuous training in attention to diversity, all the estimated coefficients are negative, but they are only statistically significant for the area of history/sociology (area 2) and the area of philology (area 3). Therefore, the average level of continuous training in the area of education in aspects related to attention to diversity is significantly higher than the average level of continuous training in the other two areas indicated. However, there are no statistically significant differences between the average level of continuous training in the areas of education and psychology (area 1). Regarding the effect of the aforementioned variables on the demands for training in attention to diversity, a similar pattern is observed, although with differences. In this case, the estimated 
coefficients are also negative, which indicates that teachers from the area of education, on average, demand more additional training than teachers in the other analyzed areas. However, in this case, there are no statistically significant differences between the average training demand in the area of education and that of the area of philology.

We end the analysis of the control variables by considering the effect of age on the dimensions of interest. Our results show that while age is not relevant when it comes to explaining the current level of continuous training in issues related to inclusive education $(\mathrm{b}=0.005 ; p=0.448)$, this variable is a determining factor in future demand for training. As observed in Table 4, the estimated coefficient of this variable is negative and statistically significant $(b=-0.021, p=0.000)$, indicating that as teachers' ages increase, their interest in receiving additional training in attention to diversity decreases. Regarding the presented mediation model, Figure 3 shows the estimated coefficients for the relationships between the dimensions considered.

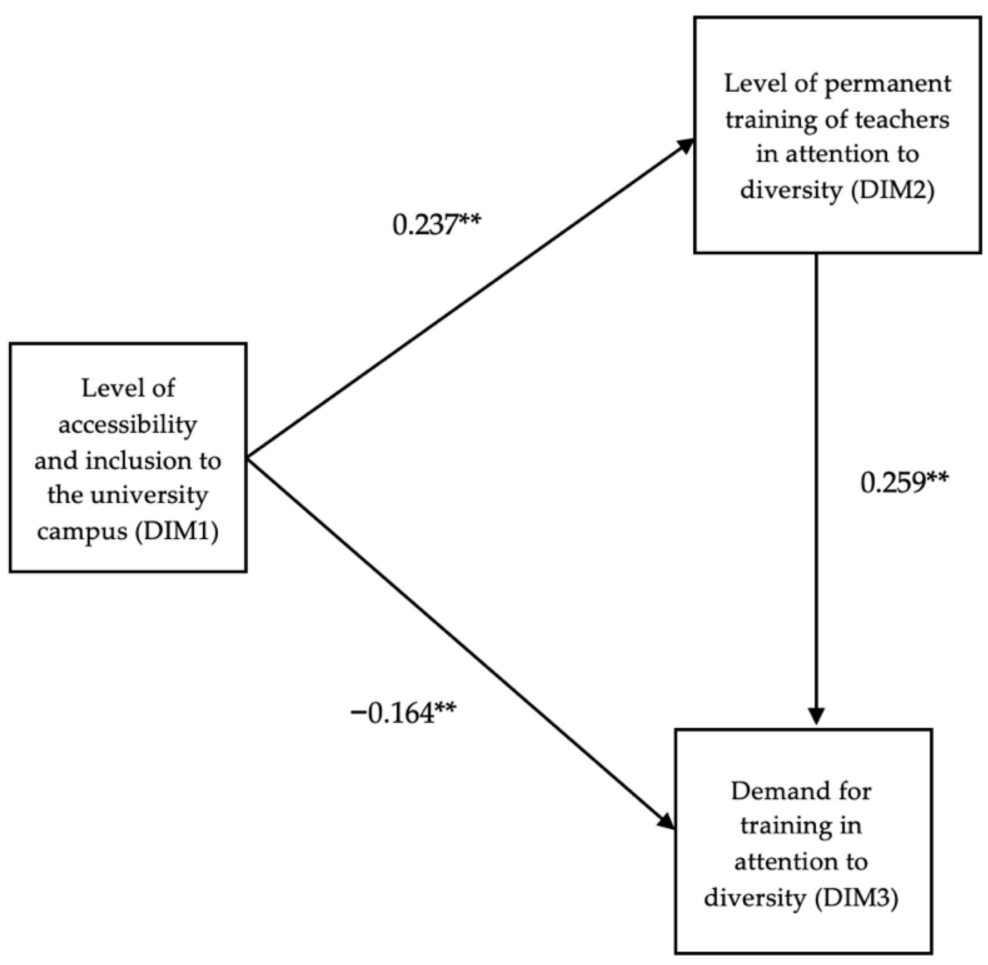

Figure 3. Mediation model: estimated coefficients (not standardized). Note: ${ }^{* *} p<0.001$.

Our results show a positive and statistically significant effect of the level of accessibility and inclusion of the university campus on the level of teachers' continuous training in attention to diversity $(b=0.237 ; p<0.001)$. On the other hand, the current level of teachers' continuous training in attention to diversity has a positive and statistically significant effect on the future demands for training in attention to diversity of teachers from the university $(b=0.259 ; p<0.001)$. However, the impact of the level of accessibility and inclusion of the university campus on training demands is negative $(b=-0.164 ; p<0.001)$. These results reveal the dual effect that the level of accessibility and inclusion of the university campus has on the demands for training in attention to diversity. While the direct effect of the level of accessibility and inclusion of the university campus on training demands is negative, the level of accessibility and inclusion of the university campus positively affects training demands through the level of teachers' continuous training in attention to diversity (indirect effect: $\mathrm{b}=0.061 ; p=0.002$ ). As a result of this dual effect, our data show that the total effect of the level of accessibility and inclusion of the university campus on the demands for training in attention to diversity is not statistically significant $(b=-0.102$; 
$p>0.05$ ); this is because the negative effect is offset by the positive sign mediated by the level of continuous training in this area.

\section{Discussion}

This study examines for the first time the double effect namely, direct and indirect effect that the level of accessibility and inclusion of eight universities in the Autonomous Community of Andalusia has on the teachers' training demands in terms of attention to diversity. The proposed model controls the effect of four factors (gender, age, previous experience with students with special educational needs, and area of knowledge) that the literature shows to be related to the analyzed variables.

From our findings, we conclude that the impact of accessibility and inclusion presented by the university campus has a direct negative effect on the training demands in attention to diversity that teachers request from the university, and an indirect positive effect mediated by the level of teachers' continuous training. The latter mediates the relationship between the accessibility and inclusion of the university campus and the training demands of the teachers in attention to diversity. Our results indicate that, as the university campus becomes more inclusive and accessible, the training of teachers in attention to diversity is greater, and a higher level of continuous training has a positive impact on the training demands in attention to diversity by the teachers. In this way, trained teachers and a sustainable environment adapted to disability are essential to respond appropriately to the needs of students with special educational needs [25].

However, the final result of this double direct (negative) and indirect (positive) effect of the level of accessibility and inclusion of the university campus on the training demands of teachers is not statistically significant. The justification for the direct negative effect may be due to the fact that there may be teachers who consider this training demand less relevant because if the campuses are accessible and inclusive, they have mechanisms, such as support services for students with special educational needs and resources, that help and advise them on how to make their classes and subjects inclusive. That is why they do not feel the need for continuous training and, therefore, do not request training from the university. Therefore, the link between the university, its services, and teachers is essential so that students with special educational needs can have equal learning opportunities $[15,16]$.

These results are of interest to academic researchers because we are unaware of other studies that have examined the mediating role played by teachers' continuous training in terms of attention to diversity on the process of training requested by teachers from the universities, considering the impact of the level of accessibility and inclusion of the university campus. The current results have also revealed conclusions of the effect that the control variables have on those variables considered in the study, and the literature shows how these control variables can influence the improvement of inclusive education in universities.

There are gender differences in the continuous training dimension, since being a woman has a positive influence on the level of continuous training in attention to diversity. Furthermore, our results show more positive attitudes from women towards the inclusion of students with special educational needs compared to men, which corroborates the conclusions of previous studies [28,29]. For this reason, we agree with Murray et al. [22] and Hong [31] because the more training in attention to diversity, the better the attitudes towards inclusion. That is why it would be advisable to focus on improving the training of men, so that inclusion will be improved jointly [27]. However, no significant differences between men and women can be found with respect to training demands in attention to diversity. The explanation for this result may be related to the fact that, although women present higher levels of training in attention to diversity than men, women feel the need to continue training in this area; thus, their demands are equal to those of men, who show lower previous training levels.

Regarding the age factor, the results show that it is not relevant in explaining the level of continuous training related to attention to diversity, although it is a determining factor in 
training demands in this area, since as the teachers' age increases, their interest in receiving additional training decreases. These results contrast with those obtained by other studies that conclude that more positive attitudes towards inclusion develop at an older age [27,34]. It is necessary to point out that, although the interest in requesting complementary training in attention to diversity decreases, this does not imply that over the time teachers develop negative attitudes towards inclusion. Rather, we assume that the negative relationship between age and training demands may be explained by the fact that throughout their academic careers, teachers have been able to attend multiple training courses and therefore do not feel the need to continue training. Furthermore, the experience accumulated while teaching students with special educational needs means that, over the years, teachers have internalized approaches to attend to their requirements, so that they do not feel the need to receive additional training to complement this experience.

In this sense, our results indicate that having previous experience with students with special educational needs is a determining factor in the level of teachers' continuous training, coinciding with Emmers et al. [30] and Suriá et al. [35], which contradicts the conclusions of related research [27]. However, we did not find significant differences in the training demands, so the attitudes of teachers may vary depending on whether or not they have worked previously with students with special educational needs.

Significant differences are observed depending on the area of knowledge to which the teachers belong, as per other studies $[27,36]$. Teachers who belong to the area of education show a higher level of continuous training in attention to diversity than those who belong to the areas of history/sociology or philology. However, there are no significant differences compared to the area of psychology. Regarding the demands for training, the results again reveal that teachers from the area of education exhibit a greater demand for complementary training if compared to those who belong to the areas of history/sociology or psychology, although we did not find significant differences with teachers from the area of philology. Consequently, teachers from the area of philology show positive attitudes towards the inclusion, since they recognize that they do not have continuous training in attention to diversity, but they demand it from their university, whereas teachers from the area of history/sociology are less likely to do so.

\section{Conclusions}

These conclusions suggest interesting recommendations for the inclusive management of university campuses in order to have better teaching professionals and thus achieve inclusive education in the higher education system. On the one hand, it has been demonstrated that there is a clear relationship between the level of accessibility and inclusion of university campuses, the teachers' continuous training in attention to diversity, and the training requested by teachers in attention to diversity from the universities. On the other hand, it is evident that having accessible and inclusive university campuses supports the interest of teachers in maintaining continuous training in attention to diversity, as well as in continuing to demand this training from universities.

Finally, if we are truly certain that we want to develop and create inclusive universities, it is clear that universities must have teachers with inclusive profiles who are interested in continuous training in order to be prepared for any situation. To this end, it is vital that universities are aware of the content most in demand by teachers and opt for enriching training programs that motivate their teachers to receive this training, and they can use accessible methodologies and materials that allow the participation of all students. In short, there is still much to be done to achieve sustainable and inclusive higher education.

Author Contributions: Conceptualization, N.G.-C. and M.J.C.-R.; methodology, N.G.-C.; software, E.C.-P.; validation, E.C.-P.; formal analysis, E.C.-P.; investigation, N.G.-C.; resources, S.P.-V.; writingoriginal draft preparation, N.G.-C.; writing-review and editing, N.G.-C., S.P.-V. and M.J.C.-R.; visualization, N.G.-C.; supervision, E.C.-P. and M.J.C.-R.; funding acquisition, S.P.-V. All authors have read and agreed to the published version of the manuscript. 
Funding: This research has been funded, in part, by the Ministry of Universities through the University Teacher Training Program, Spain (FPU2019). The support of the Ministry does not imply acceptance of its contents, which is the sole responsibility of the authors.

Institutional Review Board Statement: The study was conducted according to the guidelines of the Helsinki Declaration, and it was approved by the Ethics Committee of the University of Jaén (Ref.ABR.18/9.TES).

Informed Consent Statement: Informed consent was obtained from all subjects involved in the study.

Data Availability Statement: Not applicable.

Acknowledgments: The authors would like to thank the teachers in Faculties of Education in public Universities in Andalusia for their collaboration in the study and their suggestions for improvement.

Conflicts of Interest: The authors declare no conflict of interest.

\section{References}

1. Crisol, E. Hacia una educación inclusiva para todos. Nuevas contribuciones. Rev. Currículum Form. Profr. 2019, 23, 1-9.

2. Moriña, A. Formación del Profesorado Para una Educación Inclusiva en la Universidad; Síntesis: Madrid, Spain, 2018.

3. Banerjee, P.A. Widening Participation in Higher Education with a View to Implementing Institutional Change. Perspect. Police Pract. High. Educ. 2018, 22, 75-81. [CrossRef]

4. Fossey, E.; Chaffey, L.; Venville, A.; Ennals, P.; Douglas, J.; Bigby, C. Navigating the Complexity of Disability Support in Tertiary Education: Perspectives of Students and Disability Service Staff. Int. J. Incl. Educ. 2017, 21, 822-883. [CrossRef]

5. United Nations. Transforming Our World: The 2030 Agenda for Sustainable Development. 2015. Available online: https: / / sustainabledevelopment.un.org/post2015/transformingourworld (accessed on 21 December 2020).

6. United Nations. United Nations Convention on the Rights of Persons with Disabilities. 2006. Available online: https://www.un. org/development/desa/disabilities / convention-on-the-rightsof-persons-with-disabilities.html (accessed on 21 December 2020).

7. European Commission. European Disability Strategy 2010-2020: A Renewed Commitment to a Barrier-Free Europe. 2010. Available online: http:/ / eur-lex.europa.eu/LexUriServ / LexUriServ.do?uri=COM:2010:0636:FIN:en:PDF (accessed on 21 December 2020).

8. European Agency for Special Educational Needs and Inclusive Education. European Agency Statistics on Inclusive Education: 2014 Dataset Cross-Country Report. 2017. Available online: https://www.european-agency.org/resources/publications/ european-agency-statistics-inclusive-education-2014-dataset-cross-country. (accessed on 21 December 2020).

9. Organic Law 4/2007, of April 12, Which Modifies Organic Law 6/2001, of December 21, on Universities (BOE, n89, of April 13, 2007). Available online: https://www.boe.es/eli/es/lo/2007/04/12/ (accessed on 20 December 2020).

10. Royal Decree 1791/2010, of December 30, Which Approves the University Student Statute (BOE, No. 31, of 31 December 2010). Available online: https:/ /www.boe.es/eli/es/rd/2010/12/30/1791 (accessed on 20 December 2020).

11. Moriña, A.; Sandoval, M.; Carnerero, F. Higher education inclusivity: When the disability enriches the university. High. Educ. Res. Dev. 2020, 39, 1202-1216. [CrossRef]

12. Carballo, R.; Morgado, B.; Cortés-Vega, M.D. Transforming Faculty Conceptions of Disability and Inclusive Education Through a Training Programme. Int. J. Incl. Educ. 2019. [CrossRef]

13. Veitch, S.; Strehlow, K.; Boyd, J. Supporting university students with socially challenging behaviours through profesional development for teaching staff. J. Acad. Lang. Learn. 2018, 12, A156-A167.

14. Zhang, Y.; Rosen, S.; Cheng, L.; Li, J. Inclusive higher education for students with disabilities in China: What do the university teachers think? High. Educ. Stud. 2019, 8, 104-115. [CrossRef]

15. Knight, W.; Wessell, R.D.; Markle, L. Persistence to graduation for students with disabilities: Implications for performance-based outcomes. J. Coll. Stud. Retent. Res. Theory Pract. 2016, 19, 362-380. [CrossRef]

16. Moriña, A.; Orozco, I. Planning and implementing actions for students with disabilities: Recommendations from faculty members who engage in inclusive pedagogy. Int. J. Educ. Res. 2020, 103, 101639. [CrossRef]

17. Kilpatrick, S.; Johns, S.; Barnes, R.; Fischer, S.; McLennan, D.; Magnussen, K. Exploring the retention and success of students with disability in Australian higher education. Int. J. Incl. Educ. 2017, 21, 747-762. [CrossRef]

18. Hansen, K.D.; Dawson, D.L. "We can do better": Community college faculty preparedness for teaching students with learning disabilities. J. Divers. High. Educ. 2020, 13, 309-319. [CrossRef]

19. Melero, N.; Moriña, A.; Perera, V.H. Acciones del profesorado para una práctica inclusiva en la universidad. Rev. Bras. De Educ. 2019, 24, 1-19. [CrossRef]

20. Dementievich, P.; Yurievna, O. Characteristics of the Model of Methodological Training of a Teacher for Working in the Conditions of an Inclusive Educational Environment. Univers. J. Educ. Res. 2017, 5, 551-556. [CrossRef] 
21. Kendall, L. Supporting Students with Disabilities Within a UK University: Lecturer Perspectives. Innov. Educ. Teach. Int. 2018, 55, 694-703. [CrossRef]

22. Murray, M.; Lombardi, A.; Wren, C.T. The effects of disability-focused training on the attitudes and perceptions of university staff. Remedial Spec. Educ. 2010, 32, 290-300. [CrossRef]

23. Moriña, A.; Perera, V.H.; Carballo, R. Training Needs of Academics on Inclusive Education and Disability. Sage Open 2020, 1-10. [CrossRef]

24. Gelbar, N.W.; Madaus, J.W.; Lombardi, A.; Faggella-Luby, M.; Dukes, L. College Students with Physical Disabilities: Common on Campus, Uncommon in the Literature. Res. Advocacy Pract. Complex Chronic Cond. 2015, 34, 14-31. [CrossRef]

25. Griffiths, S. Teaching for Inclusion in Higher Education: A Guide to Practice; All Ireland Society for Higher Education: Dublín, Ireland, 2010.

26. Clavijo, R.; López, C.; Cedillo, C.; Mora, C.; Ortiz, W. Actitudes docentes hacia la Educación Inclusiva en Cuenca. MASKANA 2016, 7, 13-22. [CrossRef]

27. Llorent, V.J.; Zych, I.; Varo-Millán, J.C. University academic personnel's vision of inclusive education in Spanish universities. Cult. Educ. 2020, 32, 147-181. [CrossRef]

28. Avramidis, E.; Norwich, B. Teachers' Attitudes Towards Integration/Inclusion: A Review of the Literature. Eur. J. Spec. Needs Educ. 2002, 17, 129-147. [CrossRef]

29. Álvarez, J.L.; Buenestado, M. Predictores de las actitudes hacia la inclusión de alumnado con necesidades educativas especiales en futuros profesionales de la educación. Rev. Complut. Educ. 2015, 26, 627-645. [CrossRef]

30. Emmers, E.; Baeyens, D.; Petry, K. Attitudes and self-efficacy of teachers towards inclusion in higher education. Eur. J. Spec. Needs Educ. 2020, 35, 139-153. [CrossRef]

31. Hong, B.S.S. Qualitative Analysis of the Barriers College Students with Disabilities Experiences in Higher Education. J. Coll. Stud. Dev. 2015, 56, 209-226. [CrossRef]

32. Collins, A.; Azmat, F.; Rentschler, R. Bringing everyone on the same journey: Revisiting inclusion in higher education. Stud. High. Educ. 2019, 44, 1475-1487. [CrossRef]

33. Suriá, R. Discapacidad e integración educativa: ¿qué opina el profesorado sobre la inclusión de estudiantes con discapacidad en sus clases? Rev. Española Orientación y Psicopedag. 2012, 23, 96-109. [CrossRef]

34. Llorent, V.J.; Álamo, M. La formación inicial del profesorado en las actitudes hacia la diversidad cultural. Validación de una escala. Pap. Población 2019, 25, 187-208. [CrossRef]

35. Suriá, R.; Bueno, A.; Rosser, A. Prejuicios entre los estudiantes hacia las personas con discapacidad: Reflexiones a partir del caso de la Universidad de Alicante. Alternativas. Cuad. Trab. Soc. 2011, 18, 75-90. [CrossRef]

36. Ortiz, A.; Agreda, M.; Colmenero, M.J. Towards inclusive higher education in a global context. Sustainability 2018, 10, 2670. [CrossRef]

37. González Castellano, N.; Cordón Pozo, E.; Colmenero-Ruiz, M.J. University professors and the inclusion of students with special educational needs in Higher Education: Proposal and validation of a measurement scale. Int. J. Incl. Educ.. under review.

38. Universia Foundation. II Study on the Degree of Inclusion of the Spanish University System Regarding the Reality of Disability; CERMI: Madrid, Spain, 2014. Available online: https:/ /www.fundacionuniversia.net/content/dam/fundacionuniversia/pdf/estudios/ IIEstudio_UniversidadyDiscapacidad_ACC.pdf (accessed on 4 January 2019).

39. Universia Foundation. III Study on the Degree of Inclusion of the Spanish University System Regarding the Reality of Disability; CERMI: Madrid, Spain, 2016. Available online: https://www.fundacionuniversia.net/content/dam/fundacionuniversia/pdf/estudios/ IIIEstudio_UniversidadyDiscapacidad_ACC.pdf (accessed on 6 January 2019).

40. Universia Foundation. IV Study on the Degree of Inclusion of the Spanish University System regarding the Reality of Disability; CERMI: Madrid, Spain, 2018. Available online: https://www.cermi.es/sites/default/files/docs/colecciones/Fundacion_IVEstudio_ AAFF.pdf (accessed on 22 April 2019).

41. R Core Team. R: A language and environment for statistical computing. R Foundation for Statistical Computing; Vienna, Austria. 2020. Available online: https:/ / www.R-project.org/ (accessed on 12 December 2020).

42. Rosseel, Y. lavaan: An R Package for Structural Equation Modeling. J. Stat. Softw. 2012, 48, 1-36. [CrossRef]

43. Korkmaz, S.; Goksuluk, D.; Zararsiz, G. MVN: An R Package for Assessing Multivariate Normality. R J. 2014, 6, 151-162. [CrossRef]

44. Jorgensen, T.D.; Pornprasertmanit, S.; Schoemann, A.M.; Rosseel, Y. semTools: Useful Tools for Structural Equation Modeling, R Package Version 0.5-3. 2020. Available online: https:/ /CRAN.R-project.org/package=semTools (accessed on 12 December 2020).

45. Gana, K.; Broc, G. Structural Equation Modeling with Lavaan; ISTE and John Wiley \& Sons: London, UK, 2019.

46. Bagozzi, R.P.; Yi, Y. On the evaluation of structural equation models. J. Acad. Mark. Sci. 1988, 16, 74-94. [CrossRef]

47. Hair, J.F.; Black, W.C.; Babin, B.J.; Anderson, R.E. Multivariate Data Analysis, 7th ed.; Pearson Education Limited: London, UK, 2014.

48. Bagozzi, R.P.; Yi, Y.; Phillips, L.W. Assessing construct validity in organizational research. Adm. Sci. Q. 1991, 36, 421-458. [CrossRef]

49. Voorhees, C.M.; Brady, M.K.; Calantone, R.; Ramirez, E. Discriminant validity testing in marketing: An analysis, causes for concern, and proposed remedies. J. Acad. Mark. Sci. 2016, 44, 119-134. [CrossRef] 
50. Fornell, C.; Larcker, D.F. Evaluating structural equation models with unobservable variables and measurement error. J. Mark. Res. 1981, 18, 39-50. [CrossRef]

51. Henseler, J.; Ringle, C.M.; Sarstedt, M. A new criterion for assessing discriminant validity in variance-based structural equation modeling. J. Acad. Mark. Sci. 2015, 43, 115-135. [CrossRef] 